\title{
Interactive impacts of by-catch take and elite consumption of illegal wildlife
}

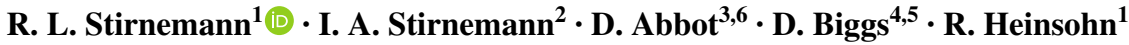

Received: 7 March 2017 / Revised: 15 November 2017 / Accepted: 25 November 2017

(C) Springer Science+Business Media B.V., part of Springer Nature 2017

\begin{abstract}
Harvesting, consumption and trade of forest meat are key causes of biodiversity loss. Successful mitigation programs are proving difficult to design, in part because anthropogenic pressures are treated as internationally uniform. Despite illegal hunting being a key conservation issue in the Pacific Islands, there is a paucity of research. Here, we examine the dynamics of hunting of birds and determine how these contribute to biodiversity loss on the islands of Samoa. We focus on the interactive effects of hunting on two key seed dispersing bird species: the Pacific pigeon (Ducula pacifica) and the critically endangered Manumea or tooth-billed pigeon (Didunculus strigiristris). We interviewed hunters, vendors and consumers and analyzed household consumption. Results suggest that over 22,000 pigeons were consumed per year and this is by primarily the richest people across the country. Indeed, the wealthiest $10 \%$ of households consumed $43 \%$ of all wild pigeon meat, and the wealthiest $40 \%$ of households consumed $80 \%$ of all pigeons. The Manumea was shot by $33 \%(n=30)$ of the surveyed hunters while pursuing the Pacific pigeon.
\end{abstract}

Communicated by Karen E. Hodges.

This article belongs to the Topical Collection: Biodiversity exploitation and use.

R. L. Stirnemann

rstirnemann@gmail.com

1 Fenner School of Environment and Society, The Australian National University, 48a Linnaeus Way, Acton, ACT 2601, Australia

2 Biodiversity and Ecosystem Research Group, Institute of Landscape Ecology, University of Münster, Heisenbergstr. 2, 48149 Münster, Germany

3 Statistics Consultancy, Vienna, USA

4 ARC Centre of Excellence for Environmental Decisions, Centre for Biodiversity \& Conservation Science, University of Queensland, Brisbane, QLD 4072, Australia

5 Department of Conservation Ecology and Entomology, Stellenbosch University, Private Bag X1, Matieland, Stellenbosch 7602, South Africa

6 IUCN CEESP/SSC Sustainable Use and Livelihoods Specialist Group, c/IUCN, Rue Mauverney 28, Gland, Switzerland 
Results raise serious conservation concerns, as pigeon hunting is likely to be a key factor contributing to the decline of the Manumea and critical forest seed dispersers in general. Our results show that wild meat consumption can lead to non-targeted pressure on bycatch species. Wild meat harvesting and consumption is a key issue leading to species declines and extinctions in the tropics. It is critical that this issue receives the appropriate attention and is addressed in the Pacific if species and forests are to be maintained.

Keywords Bushmeat $\cdot$ Illegal wildlife trade $\cdot$ Supply chain $\cdot$ Poaching $\cdot$ Hunting $\cdot$ Inequality

\section{Introduction}

Hunting and harvesting of wildlife is a key threat to biodiversity (Bodmer et al. 1997; Bennett et al. 2002; McCauley et al. 2015). Such harvesting can be legal or illegal and for the purpose of food, stature, traditional medicine among others (Phelps et al. 2016; Cooney et al. 2016). Mitigating threats from hunting pressure requires a clear understanding of the motivations of consumption and of the supply chain, the mechanism(s) by which the meat from hunting is moved from the site of capture to the consumer's table (Duffy et al. 2016). It has been argued that hunting is motivated by the basic need for food to sustain livelihoods with limited options and income, particularly for low-income communities (Robinson and Bennett 2002; Fa et al. 2003; De Merode et al. 2004; Kümpel et al. 2010). However, recent research has suggested that forest wildlife hunting is not always driven by a dependence on hunting as a protein source (Bassett 2005; Fa et al. 2009). Instead in many cases, it is a form of elite or conspicuous consumption for special events or by the wealthy in a community (Milner-Gulland and Bennett 2003; Mace et al. 2008).

Indeed, there is evidence of more nuanced interactions between hunting, consumption, and threats to wildlife occurring (see van Vliet and Mbazza 2011). For example, lowincome individuals may be provided with cash incentives to hunt species sought after for consumption by the wealthy elite. For example, in some African countries poachers have been paid a relatively high price compared to the local incomes to poach species, such as rhino and elephants, by East Asian consumers with relatively high expendable incomes (Challender and Macmillan 2014).

Although elite consumption of bushmeat and high value products like rhino horn have been established in Africa, the pressures of elite consumption on other smaller taxa has not been explored. The negative impacts of hunting and the commercial bushmeat trade are well documented in many regions in the world, such as Equatorial Africa (Fa et al. 2003; De Merode et al. 2004; Effiom et al. 2013), the Amazon (Bodmer et al. 1997; Peres et al. 2016) and Southeast Asia (Corlett 2007; Steinmetz et al. 2014; Harrison et al. 2016). However, there is little published literature on this issue from the Pacific Islands (Craig et al. 1994; Watling 2004; Walker 2007; Szabo et al. 2012; IUCN 2015). This is despite illegal hunting pressure being known to be having a negative impact, which is linked to both the decline and extinction of numerous species in the area (Craig et al. 1994; Watling 2004; Walker 2007; Szabo et al. 2012; IUCN 2015). This lack of information obscures the creation of effective consumer-centered interventions. There is a clear need for empirical studies in the region so appropriate methodologies can be developed.

This study focuses on the hunting and consumption of illegally sourced wild bird species, with a focus commonly hunted on wild native pigeon species in the Pacific Islands of 
Samoa, and assesses the impacts of elite consumption on the supply chain. The objectives of the present study were, to determine: (1) the relationship between consumer income and illegal wild bird meat consumption, (2) the drivers of consumption and hunting, (3) the mechanism and pathway of the supply chain and, (4) the impact of hunting pressure on non-target species. We explored the implications of these results for current conservation interventions tackling illegal trade and detail how our research informs future consumer centered conservation actions.

Samoa has 82 species, of which 10 are endemic, 5 have been introduced by humans and 23 are rare or accidental, of these species historically pigeon were the main bird species hunted and consumed. For instance, surveys in 2006 by the Samoan government showed that half of the 221 people surveyed had eaten pigeon since the ban was implemented (MNRE 2006).

Samoa has six species of native pigeon: the white-throated pigeon (Columba vitiensis), friendly ground dove (Alopecoenas stairi), many coloured fruit dove (Ptilinopus perousii), crimson-crowned fruit dove (Ptilinopus porphyraceus), the Lupe or Pacific pigeon (Ducula pacifica), and the Manumea or tooth-billed pigeon (Didunculus strigirostris) and one introducted species the rock pigeon (Columba livia).

Of these, only the Manumea is endemic to Samoa. It is currently listed as Critically Endangered on the IUCN red list (2015). The Pacific pigeon, locally known as the Lupe, is currently listed as Least Concern by the IUCN red list (2012); however this species is in decline in many places in the Pacific (Park et al. 1992; Powlesland et al. 2008; IUCN 2012). Pacific Island pigeons are known to be affected by hunting with no other non-wild source of meat being available (Merlin and Juvik 1985; Walker 2007; Collar 2015). The loss or significant decline of pigeons, in particular, is likely to have significant consequences for ecosystem services, such as the dispersal of the large-bodied seeds and the consequent regeneration of native forests (McConkey and Drake 2006; Brodie et al. 2009).

Current estimates suggest less than 250 Manumea remain in the wild (Collar 2015). Hunting, habitat losses due to cyclones and deforestation as well as invasive predator impacts are thought to be the primary reasons for the decline of the Manumea (Collar 2015). However, there continue to be many gaps in our knowledge of this rare species (Collar 2015). For instance, little is currently known about the species breeding biology (Collar 2015). However, a slow life-history strategy is likely given that the species is tropical, and reports suggest a clutch size of 1-2 (Stirnemann et al. 2016); Collar 2015). The Manumea has also been recorded as roosting in low trees and bushes at night which may have resulted in higher predation rates from cats (Pritchard 1866). A slow life-history strategy would increase the impact of mortality due to hunting or invasive species on recovery and probably explain why the Manumea and Lupe have declined at different rates (Stirnemann et al. 2016).

Pacific pigeons and Manumea have long been hunted in Samoa (and in neighbouring Tonga and American Samoa) with elaborate traps on stone platforms called tia seulupe or star mounds (Burley 1996; Collar 2015), Pritchard 1866). The sport of pigeon hunting was firmly associated with the chiefly elite (Burley 1996).Village chiefs with high status competed to catch the most Pacific pigeons, using a tame bird as a decoy and a longhandled net to sweep up attracted individuals (Herdrich 1991; Burley 1996; Collar 2015). These records suggest Pacific pigeons were once very abundant. Manumea were also hunted and possibly preferred over the other columbids (Collar 2015). The methodology of pigeon hunting in Samoa altered with the arrival of guns. Between 1978 and 1979, Collar (2015) reported that Manumea were 'hunted throughout the year' and that 'one local hunter estimated that one of every 10 or 12 pigeons shot belonged to this species'. In 1985 
Beichle and Maelzer estimated that 400 Manumea were hunted every year. In 1993, a ban on pigeon hunting under the protection of wildlife regulation was drafted and implemented (MNRE 1998). However, surveys in 2006 by the Samoan government showed that half of the 221 people surveyed had eaten pigeon since the ban was implemented (MNRE 2006).

\section{Methods}

\section{Study area}

The Samoan archipelago $\left(13^{\circ}-15^{\circ} \mathrm{S}, 168^{\circ}-173^{\circ} \mathrm{W}\right)$ is located in the south Pacific, northeast of the Fiji archipelago. It is politically divided into Samoa and American Samoa. Samoa consists of two main islands: Upolu $\left(1110 \mathrm{~km}^{2}\right.$ area; maximum elevation $\left.1100 \mathrm{~m}\right)$ and Savai'i (1820 km²; maximum elevation $1860 \mathrm{~m}$ ) (Ward and Ashcroft 1998). The main wet season is from November to April, but there is high rainfall at high elevation $(+600 \mathrm{~m})$ all year (approx. 600-800 cm of rainfall annually) (Ward and Ashcroft 1998). Samoa's holds a human population of approximately 190,000. The majority of land in Samoa is customary land managed by family in villages (Ward and Ashcroft 1998).

Prior to human arrival, both major islands were covered with rainforest at lower elevations and cloud forest at higher elevations, with small areas of recent lava flows (Whistler 1980). Currently, little pristine lowland forest remains in Samoa, and the majority of what is present has been logged (Whistler 1980). In addition to human-driven forest loss, cyclones have also had a severe impact on Samoa's forests, altering structure and resulting in high tree mortality (Elmqvist et al. 1994).

\section{Data collection}

\section{Socioeconomic household survey}

In 2013 and 2014, the Samoa Statistics Bureau conducted a Household Income and Expenditure Survey (hereby Socioeconomic household survey) in 2348 households across Samoa (HIES 2016). Permission was given by the Statistical Department of Samoa to utilize the Socioeconomic household survey data in our study. Ethics guidelines were followed and approval obtained from Australian National University: Ethics number 7759 in order to undertake hunter surveys. This survey provided a statistically robust dataset on food and non-food consumption expenditure over a 12-month period and included details of local food, including wild birds, fish and bats consumed. The Socioeconomic household survey was conducted in four regions: (1) the Apia urban area, (2) northwest Upolu, (3) the rest of Upolu and (4) the Island of Savai'i. Between 8 and $9 \%$ of houses in each of the four regions were sampled, and each household was required to keep a detailed daily diary of food consumed and other items purchased over four 2-week periods (April and October 2013 and March and April 2014). Interviews also captured recalled information on other non-regular expenditure. Diary information was categorized in broad categories (e.g., pigeons, bats and chicken).

We examined data collected on the consumption of one item listed in the Classification of Individual Consumption According to Purpose expenditure category codes as 11201701 fresh, chilled or frozen meat from wild pigeon. No other wild birds were recorded as either 
caught and consumed by the household or purchased from someone else. Some wild pigeons may also have been gifted.

The HIES dataset was also used to calculate the total weekly expenditure per household in each region. Weekly expenditure was used as an indicator of household wealth. This metric was converted to deciles where the first decile referred to the $10 \%$ of households in each region that had the lowest per capita total weekly expenditure and the tenth decile referred to the $10 \%$ of households with the highest levels of total weekly per capita expenditure.

To compare the costs of different meat options (i.e., wild and farmed animal products), we also surveyed a haphazard selection of supermarkets and shops selling meat to determine the cost of purchasing different types of meat. The estimated unit value of wild birds (e.g., pigeons) consumed was recorded in the diaries; this value was based either on the household's estimate of the value of each bird or on the actual price paid if purchased. We used the data recorded in the diaries to calculate the number of wild birds consumed. Consumption of wild birds was analysed in relation to the capita total weekly expenditure.

\section{Hunter interviews}

To obtain information on hunting activities and the consumption of wild birds, we conducted face-to-face interviews (hereby hunter interviews) using a standardized questionnaire with both multiple choice and open-ended questions (Appendix). In total, 40 people [30 hunters (age of hunters interviewed range 39-63, mean 50.5 years), and 10 non-hunting consumers] were interviewed across Samoa in both the islands of Savai'i and Upolu. We undertook interviews of the hunters known to the rest of the village and they often helped us identify other hunters. Interviews took place over a period of 17 months between January 2015 and July 2016. Interviews were conducted in a language the interviewees were comfortable with, either Samoan or English. All four assistants received training in social research methods prior to data collection (i.e., how to question the interviewee without giving leading questions and how to fill out the form). Consumers were informally interviewed to gain an understanding of the food chain and market mechanisms. Ethics guidelines for hunter interviews were followed and approval obtained from Australian National University: Ethics number 7759.

We categories hunters as either: (1) subsistence hunters, who hunt for family consumption and (2) commercial hunters who hunt for an income. However, there was so much cross over between categories we ultimately grouped them into a single category. An additional hunting group was identified during informal interviews as sport hunters. Further insights into this group of hunters would be useful in future studies. We defined retailers as individuals who purchased meat and on sold to someone else.

We recorded information on the interviewee demographics, target bird species (e.g., pigeon species), hunting activities (i.e., hunting frequency), location of favored hunting areas and general meat preferences. We also asked people to rank pigeon meat in comparison to other local meat/fish available. During the interview, we established if the interviewee could identify different pigeon species. The motivation of this question was to determine what species were deliberately targeted. 


\section{Results}

Pigeons were the only wild bird species recorded being consumed in Samoa (HIES data). Results from the HIES data indicate approximately 22,000-33,000 pigeons are consumed each year. Indeed, all hunters (100\%) surveyed could be defined as hunting for both sustenance and commercial purposes. However, informal interviews demonstrated there was a second smaller group of hunters, sport hunters. This group of hunters is made up of wealthier business owners who hunt as a hobby and for personal consumption. These hunters did not take part in the formal interviews.

Our results from the hunter surveys indicate that two species of pigeon are hunted and consumed within Samoa-the Lupe and Manumea. However, hunters tended to target the Pacific pigeon. For example, in most cases when the Manumea $(n=30)$ was shot, the Pacific pigeon was the target species. All $(100 \% ; n=30)$ of the hunters and all the consumers who were not hunters $(\mathrm{n}=10)$ stated the meat of the Manumea was not very appetizing and therefore not targeted. However, despite this, thirty percent $(\mathrm{n}=30)$ of hunters reported they had accidentally shot at least one Manumea during their hunting career (range 19-43 years, mean 30.5 years, std dev 8.2), with $27 \%(\mathrm{n}=30)$ of the surveyed hunters having accidentally shot multiple individuals. Accidental shooting of Manumea was most commonly reported as occurring over 3 years ago, but was also reported to have occurred twice in 2016. On average, hunters who sold over $90 \%$ of the meat made $4-5$ hunting trips per week unless limited by bullet availability $(n=12)$. These hunters reported an average of 10-15 pigeons were shot per hunting trip.

We can calculate the number of shooting days as the number of pigeons consumed divided by the number shot per day. Assuming 22,000 pigeons are hunted and given that the surveys revealed that 10-15 pigeons were shot per day, this calculation would estimate 1466-2200 pigeon shooting days occur per year. Given the average of 4-5 hunting trips per week over a seasonal 7 month period, it is estimated that approximately 73-114 hunters would be actively shooting pigeons for consumption in Samoa. The total expenditure on pigeon meat is estimated from the HIES data at USD 129,181 ( 1 USD $=2.56087$ WST) annually.

\section{Extent of pigeon hunting}

Of the 30 interviewed hunters, 93\% stated that pigeons were considered to be a seasonal resource (hereby referred to as seasonal hunters), with October to December and June to December being recorded as the most commonly listed months for hunting. The other $7 \%$ of non-seasonal hunters hunted pigeons throughout the year. The main reasons given for seasonal hunting was the fruiting of food trees preferred by pigeons, such as Ma'ali (Canariun samoense) between October and December, and Moso'oi (Cananga odorata) between June and December. Seasonal hunters stated that hunting during these time periods "made the pigeons fatty and more tasty". However, the availability of pigeons for special Samoan festival dates, such as the White Sunday feast in early October, the special day for children in Samoa, was also important for consumers as pigeons were traditionally eaten during these times of the year. Non-seasonal hunters collected Pacific pigeons for any special occasion, such as when guests came to the village or as gifts. Pigeon meat was gifted to people by $60 \%(n=23)$ of the hunters surveyed. These hunters stated that they had gifted to people within the community, such as "pastors", "church leaders", "high chiefs" and "older family members". Pigeon meat was considered to be a valuable gift 
due to the flavor and high market price. When compared to other meat types (fish, beef, chicken, lamb) pigeon meat was consistently ranked the highest, in terms of taste by all surveyed people who had tried pigeon meat $(100 \%, \mathrm{n}=18)$.

Our study also investigated where wild meat consumption occurred. We found consumption occurred across the country in both regional areas in Savai'i and Upolu and the main City of Apia (Fig. 1). However, the majority of consumption is occurred away from the central City of Apia and in the northwest area of Upolu and in Savai'i (Fig. 1). Because of village rules, which are strictly enforced, pigeon hunting in some village areas is limited or banned completely. However, some villagers $(n=4)$ stated that even if they no longer hunted on their own lands, hunters from neighboring villages are coming and shooting on their land. None of the surveyed hunters $(0 \%, \mathrm{n}=30)$ or consumers $(0 \%, \mathrm{n}=10)$ believed that the Pacific pigeon population was overharvested or that hunting was impacting Manumea populations.

\section{Supply chain}

Our formal and informal interviews showed hunters were composed of two groups: (1) sport hunters, (2) commercial/subsistence hunters. Sport hunters typically were wealthier business owners who came from outside the village to hunt as a hobby and for personal consumption. The other group was typically using village land for hunting. When hunting for commercial purposes hunters often shot between 10 and 15 Pacific pigeons in a single day. Part-time commercial and/or subsistence hunters and wealthier commercial hunters from Apia often targeted bats in addition to pigeons.

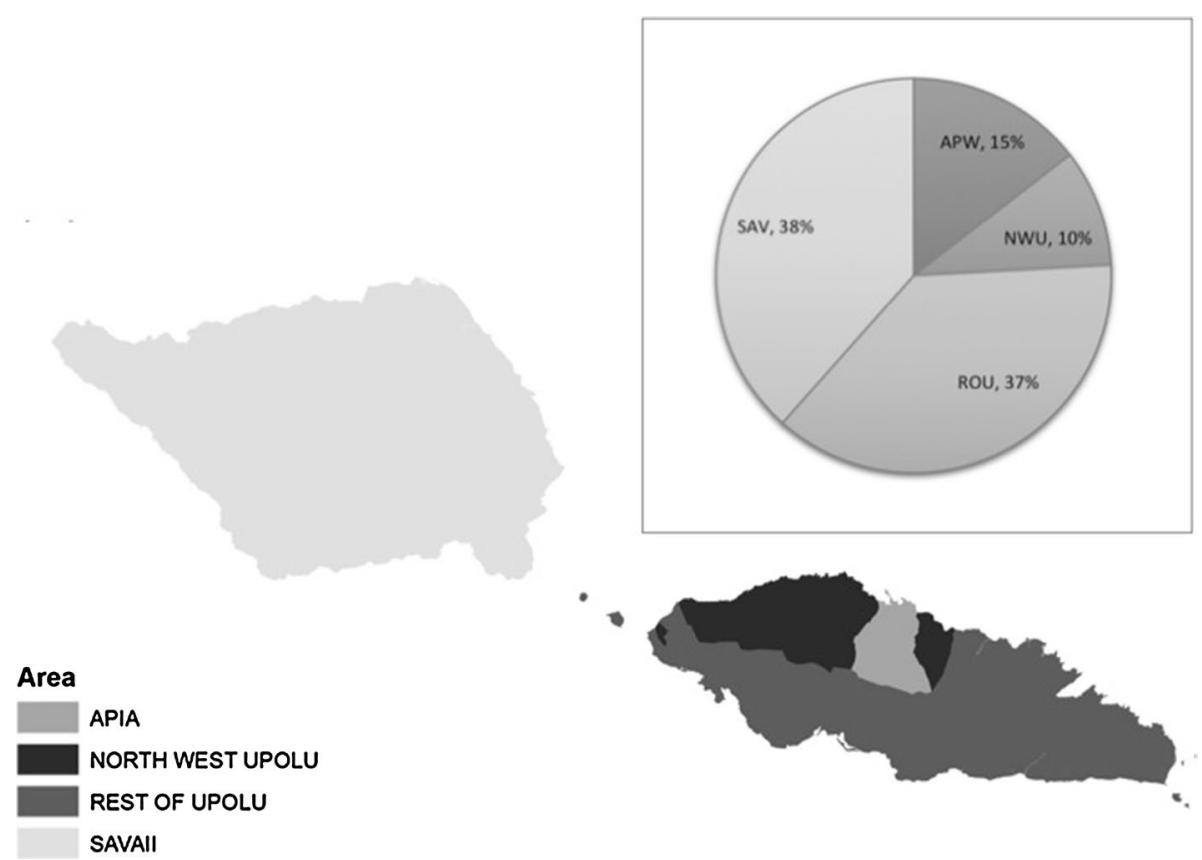

Fig. 1 The percentage of pigeon consumed (pie chart) in each of the four HIES areas (mapped) Savai'i (SAV) and Upolu (regional NWU and ROU) and the capital city of Upolu, Apia (APW) 
Two different types of traders were identified: (1) restaurants that purchase from vendors and (2) vendors who trade to non-hunting consumers. All vendors we spoke with were also hunters. However, some hunters, acting as middlemen, sold pigeons to other vendors. Vendors did not sell in the markets but instead went door-to door-visiting targeted customers. Three commercial hunters reported selling to customers who sought them out deliberately and pre-arranged pigeon orders. Some vendors also on-sold to restaurants and most had regular customers.

The pigeon meat supply chain in Samoa (Fig. 2) is in part regulated by a variety of networks of power and control (i.e., through local chiefs, regional and national government officials and the police through control of firearms and ammunition sales). However, the Samoan police regulates access to ammunition for firearms. To sell firearm ammunition legally, each retailer must obtain a permit from the police, which must be renewed annually. The annual license fee for retailers to sell ammunition was 200 WST prior to 2012 but has now been increased (2016) to $1000 \mathrm{WST} /$ year. All retailers confirmed that buyers also needed permits from the police to purchase ammunition. In addition, it costs 20 WST to license a gun annually. However, none of the retailers reported maintaining a record of how much ammunition they sold or bought annually or had any information on species that are illegal to shoot.

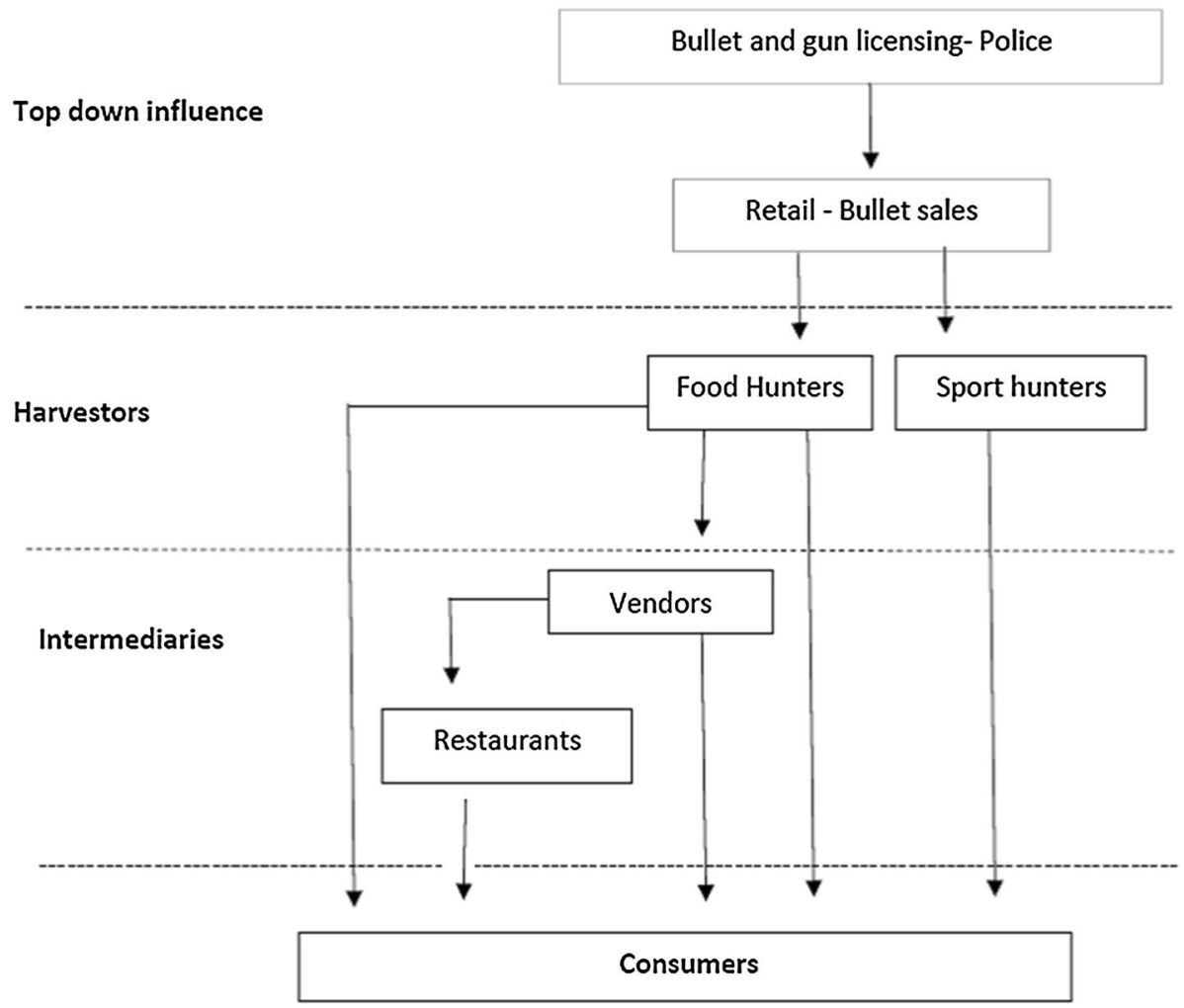

Fig. 2 Points of intercept where control can potentially occur to reduce illegal wildlife trade prior to and within the supply chain 
Changes to ammunition and gun access since 2012 have limited some wildlife hunting activity by reducing the number of bullets sold to bullet vendors and thus the amount of ammunition permitted for sale by the ammunition retailers. Indeed, a number of village hunters stated that ammunition was difficult to obtain, reducing the amount of hunting of both pigeons. Other hunters reported wealthy patrons who provide firearms and ammunition or finance the purchase of those items in exchange for supplying pigeons.

\section{Livelihood value of hunting}

On average, the value of a pigeon ranged between SAT10.00 and 15.00 each. These prices were consistently high. Pigeon hunting is therefore a profitable business given that the average household income in 2013-2014 was 685.60 WST/week (SBS 2016). Even taking account of the cost of ammunition [average cost for a box of 12-gauge shot was SAT35.00, for shotgun shells ( 25 per box) was SAT65 in 2016, and for a box 0.22 calibre (50 per box) was SAT35] and gun license fees (assuming the firearm used is licensed), a single day of hunting pigeons with an average of 10-15 birds shot per day will earn between SAT100 and 225 in sales. Pigeon meat costs approximately SAT27.23-35.56/kg. Pigeon was more expensive than other meat types available for purchase. Indeed, pigeon was nearly nine times more expensive than chicken, the cheapest meat available for purchase. There were no discounts to our knowledge for buying pigeons in bulk.

The consumption dataset shows that people in the wealthiest decile were the dominant consumers of pigeon (Fig. 3), with the top $40 \%$ consuming $79.5 \%$ of all pigeons. The lowest decile (10\%) consumed no pigeons (Fig. 3). Consumption was predominantly undertaken by the wealthiest people across the country.

\section{Discussion}

A better understanding of what motivates people to hunt illegally is needed to minimize biodiversity loss from that source (Duffy et al. 2016). Here, we demonstrate how consumption of wild birds was predominantly undertaken by those with the highest household income. Furthermore, we highlight the conservation impacts of hunting on a non-target species.

Fig. 3 Percentage of native pigeons consumed in Samoa by different income groups ranked from lowest to highest income deciles

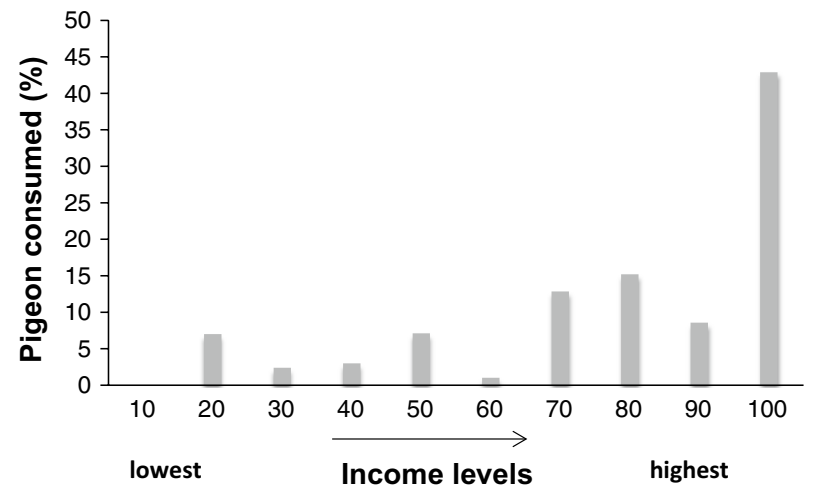

Springer 


\section{Species targeted and drivers of consumption}

Our findings indicate wild native pigeon are the only wild birds being targeted and consumed in Samoa. These findings contrast with other countries in the Pacific where seabirds [e.g., New Zealand, Lyver et al. 2015, Nauru, Buden 2008] are targeted for consumption, as well as historical data which indicates that Pununi (Gallinula pacifica), a small Samoa rail, were also hunted in Samoa prior to population declines (Pritchard 1866). Furthermore, we found that large numbers of wild native pigeons are hunted and consumed every year in Samoa. Our results indicate that poorer members of society infrequently consume pigeons even if they may be undertaking the hunting; instead, consumption is undertaken primarily by the wealthier individuals. Given that consumption by the elite is the primary driver of hunting activity and that even with other incomes available the profit gained from hunting is substantial, it is unlikely that alleviation of poverty in rural areas will successfully improve conservation outcomes for these species. Instead, surveys indicate that consumption by the elite is likely to occur in part because these wild meat foods are valued for their flavor, high market price and the associated status linking consumption to prestige and wealth. This is probably because these households have the discretionary income to spend on expensive food, while the poorer households buy the cheaper options, such as chicken. In Samoa, historically, pigeon meat was a high-status food hunted by high chiefs (Burley 1996). Our survey results suggest that this link between consumption and high status has not altered.

The problem of illegal wildlife consumption being driven by those in positions of high prestige and wealth is now a global issue (Corlett 2007; Zhang et al. 2008; Harrison et al. 2016; Phelps et al. 2016). For example, in China, the main consumers driving illegal wildlife trade are young educated males with good incomes (Zhang et al. 2008). It is critical that these drivers are considered when designing mitigation strategies and when predicting the impact of the future market. Increases in status are also occurring as the numbers of chiefly titles in Samoa, which are split in response to population increases, produce more positions of higher status. If wealth/status is a driver of consumption, it can be expected that a shift toward further increases in middle and upper classes and more people accessing greater income levels will create a higher demand for this high-status food.

\section{Implications for management}

Our research identified the pigeon meat supply chain involved in the process of pigeon trade and consumption in Samoa (Fig. 2). We outline potential management techniques that could intercept the various points in the supply chain. Four points of intercept (action preventing hunting) were isolated by this study: (1) top-down influencers (firearm and ammunition licensing and retail), (2) harvesters, (3) intermediaries and (4) consumers (Fig. 2).

Firearm and ammunition licensing and retail can have a top-down effect on the entire supply chain. Action could take the form of decreasing or banning the sale of ammunition suitable for hunting pigeons on the wing-i.e., shotgun pellets/bird shot. Such restrictions would have the greatest impact on illegal pigeon hunting and thereby in reducing Manumea bycatch. While pigeons can also be hunted using 0.22 calibre firearms when birds are feeding or roosting, this usually requires the hunter to sight the target bird for long enough to distinguish between the Pacific pigeon and Manumea, thereby providing an opportunity for hunters to reduce Manumea bycatch. 
Different types of intervention may be needed to target different types of hunters (Phelps et al. 2016). In Samoa, hunting from villages may be reduced by using existing village community structures to restrict hunting. This restriction would only be likely to occur if villages are successfully convinced to impose the necessary bans and if they are willing to enforce them (Ostrom 2008). However, the effectiveness of such bans may be reduced because neighboring villages may not respect the ban. Restricting hunting through village enforcement will also not be effective with the sport hunters who operate outside village systems. Instead, police enforcement and education targeted at this group may be required. An alternative option to completely banning hunting might be to have strong enforcement in core Manumea protected areas and have other safe areas where seasonal legal hunting activity could occur. This would, however, require further research to determine the spatial and seasonal drivers of Manumea movements to designate appropriate protected areas and, conversely, 'safe' areas for hunting where Manumea are unlikely to be present.

Understanding the motivations of the hunters is also important. Low-income individuals gain substantial profits for hunting pigeons, and therefore, profit could be an indirect driver for hunting activity as long as there is a market. The expected profit from pigeon hunting is likely to drive the continual hunting of pigeons as long as there are consumers. Because hunting is largely driven by the consumer chain, if profit is reduced or the likelihood of punishment in some form (village fines/criminal conviction) is increased, hunting activity is expected to decline (Cooney et al. 2016; Biggs et al. 2016). This provides a strong strategic reason to allocate capital towards a psychologically effective campaign reducing demand of wild meat by the elite. Alternatively, Importation of pigeons or breeding them in country is a potential management intervention which could be considered. However, care would have to be taken that this does not result in an alternative market tier opening up of wild verses domestic meat as previously seen with the bear bile market (Mills 1994).

The international community is currently focused on cross-border trade of wild meat. This is failing to address overexploitation of wildlife within countries because hunting and consumption of wild meat is largely a local issue. It is critical that the impacts of hunting in the Pacific are highlighted and appropriate action is taken. Stronger laws, penalties and enforcement are needed for all aspects of the supply chain from hunting to consumption in addition to the appropriate campaigns. Unless there is a strong change in efforts to reduce wildlife exploitation, the region will likely lose most of its iconic species, within the next few years. Given that seed dispersers are key target species this will also have considerable ecosystem repercussions (McConkey and Drake 2006; Brodie et al. 2009).

\section{Conservation implications for Manumea}

Our findings show how despite not being a target species, the Manumea or tooth-billed pigeon, the last remaining species in the Didunculus genus, is killed incidentally while hunters are targeting the Pacific pigeon. The impact of being by-catch for a critically endangered species even infrequently killed is a serious additional risk/threat. Other species, such as the Saola (Pseudoryx nghetinhensis) an antelope species incidentally captured in snares targeting other wild meat for Chinese medicine, are similarity emerging as conservation problems (Corlett 2007; Schaller and Rabinowitz 2009). Although there are few studies of terrestrial by-catch in the literature, the issues that effect by-catch species in marine environments are likely to occur in terrestrial environments. For instance, a by-catch species can be at greater risk than a targeted species (Hutchings and Reynolds 2004) because the "effort" needed to successfully hunt the by-catch species is determined by the "effort" to capture the target species. In contrast to a target species, for a by-catch 
species, there is no point at which the capture effort will decrease, unless the target species is no longer hunted (Hutchings and Reynolds 2004). Therefore, if the by-catch species has a demographic which makes the harvesting unsustainable or is range-restricted, the impact of increased mortality is expected to be greater (Tuck et al. 2001). Although little is still known about the life cycle of the Manumea, many tropical species are slow breeders with low fecundity (Stirnemann et al. 2016). Therefore, the extinction risk to the critically endangered Manumea from Pacific pigeon hunting needs be taken seriously. Furthermore, we highlight that by-catch impacts may be more important in terrestrial systems than originally thought. We suggest further investigations on the impact of incidental hunting on terrestrial species are needed. However, even more importantly an effective campaign to change the behavior of pigeon consumers should be a priority for Manumea conservation.

Efforts to reduce pigeon hunting will not only aid in reducing the risk of extinction for the Manumea but are also essential for retaining ecosystem health and function. Large pigeons are important large-seeded tree dispersers in forest ecosystems (Harrison et al. 2016). The forests of Samoa are increasingly under pressure from development and are dominated by invasive plant species, with flow-on effects for the terrestrial and near shore marine environment (Ponzi et al. 2004). For widespread change which will save forests and the important large bodied seed dispersers, it will be necessary to combine the strategies of publicity and education.

Globally elite consumption is an important driver of wildlife trade, and understanding the supply chain is critical to identifying interventions to reduce risks to species and habitats. Despite recent research showing wealthy consumers can drive the food chain (MilnerGulland and Bennett 2003; Mace et al. 2008) many donors continue to direct funds towards alleviating poverty and assume a link between poverty reduction and positive conservation outcomes. Though in some cases this poverty eluviation may reduce the pressure on wildlife (Vasco and Sirén 2016). Our study shows that poverty alleviation may instead have the opposite effect for wildlife trade and forest health and that this is a dynamic that requires careful consideration.

Acknowledgements We are grateful for the Grants from the Darwin DEFRA Project 21-001, Auckland Zoo and the Rufford Conservation Grant which have supported this Project. We also thank the Samoan government and Ministry of Natural Resources, Australian National University and the Samoa Conservation Society for their support in implementing this Project. In additional we thank the Samoa Statistics Bureau for allowing us to use the HIES data for this study. We are grateful for all participants in the field and the support for all the villages and local people who took part in the surveys and without whom this Project would not be possible. Further, thanks to Tiffany Straza, Greg Shirley, Mark O'Brien and Tommy Moore for all their input into the manuscript in its development and to Ryan Wright for his graphing of the HIES sites.

\section{Appendix: English version of hunting survey}


Name:

Village:

GPS location:

Age:

Sex:

1) a) Current hunter (within one year)

b) used to be a hunter (> 1year)

c) don't hunt

2) What species do you and your community hunt?
(Hunter
a) Targets manumea
b) Accidently shot manumea
c) Avoid Manumea)

3) How often do you hunt (e.g. as a community/group)?

4) Are there any species you avoid hunting?

5) Can you rate the tastiest meats?
a) cow
b) pigeon
c) Fish
d) sheep
e) chicken
f) bat

6) Do you know the difference between the Manumea, lupe or white throated pigeon?

7) Who eats the pigeons? 
8) Who eats the bats?

9) Is there a hunting season?

(le. white Sunday)

Why is this the season?

10) Is there a season when pigeons are not hunted?

Why is this?

11) Have you or your group ever shot a Manumea? Can you tell us about that?

12) Why is the bird still hunted by your community?

13) How often do you (or your community) shoot pigeons?
a) a few times a week
b) a few times a month
c) irregularly (3-6 times a year)
d) not at all. They target other species such as....

14) Where do you hunt?

A) Their village land

B) non-village land

C) Other peoples village land

15) Are you willing to show us the location on a map?

16) How many pigeons do you tend to shot?

Location scale

Where do they see Manumea and where don't they. Describe type of forest- open closed planation edge of forest.

16) The last time you shot a bird, what was the bird doing?

17) Do you sell pigeons? Can you tell us about it? How much do you get for pigeons? 


\section{References}

Bassett TJ (2005) Card-carrying hunters, rural poverty, and wildlife decline in northern Côte d'Ivoire. Geogr J 171:24-35

Beichle U, Maelzer M (1985) A conservation programme for Western Samoa. Conservation of tropical forest birds. Technical Publication 4. International Council for Bird Preservation, Cambridge, p 297-299

Bennett EL, Milner-Gulland EJ, Bakarr M, Eves HE, Robinson JG, Wilkie DS (2002) Hunting the world's wildlife to extinction. Oryx 36:328-329

Biggs D, Cooney R, Roe D, Dublin HT, Allan JR, Challender DWS, Skinner D (2016) Developing a theory of change for a community-based response to illegal wildlife trade. Conserv Biol. https://doi. org/10.1111/cobi.12796

Bodmer RE, Eisenberg JF, Redford KH (1997) Hunting and the likelihood of extinction of Amazonian mammals. Conserv Biol 11:460-466

Brodie JF, Helmy OE, Brockelman WY, Maron JL (2009) Bushmeat poaching reduces the seed dispersal and population growth rate of a mammal-dispersed tree. Ecol Appl 19:854-863

Buden D (2008) The birds of Nauru. Notornis 55:8-19

Burley DV (1996) Sport, status, and field monuments in the Polynesian Chiefdom of Tonga: the pigeon snaring mounds of northern Ha' apai. J Field Archaeol 23:421-435

Challender DWS, MacMillan DC (2014) Poaching is more than an enforcement problem. Cons Lett 7:484-494

Collar NJ (2015) Natural history and conservation biology of the tooth-billed pigeon (Didunculus strigirostris): a review. Pac Conserv Biol 21:186

Cooney R et al (2016) From poachers to protectors: engaging local communities in solutions to illegal wildlife trade. Conserv Lett. https://doi.org/10.1111/conl.12294

Corlett RT (2007) The impact of hunting on the mammalian fauna of tropical Asian forests. Biotropica 39:292-303

Craig P, Morrell TE, So'oto K (1994) Subsistence harvest of birds, fruit bats, and other game in American Samoa, 1990-1991. Pac Sci 48:344-352

De Merode E, Homewood K, Cowlishaw G (2004) The value of bushmeat and other wild foods to rural households living in extreme poverty in Democratic Republic of Congo. Biol Conserv 118:573-581

Duffy R, St John FAV, Büscher B, Brockington D (2016) Toward a new understanding of the links between poverty and illegal wildlife hunting. Conserv Biol 30:14-22

Effiom EO, Nuñez-Iturri G, Smith HG, Ottosson U, Olsson O (2013) Bushmeat hunting changes regeneration of African rainforests. Proc R Soc Lond B 280:20130246

Elmqvist T, Rainey WE, Pierson ED, Cox PA (1994) Effects of tropical cyclones Ofa and Val on the structure of a Samoan lowland rain forest. Biotropica 26:384-391

Fa JE, Currie D, Meeuwig J (2003) Bushmeat and food security in the Congo Basin: linkages between wildlife and people's future. Environ Conserv 30:71-78

Fa JE, Albrechtsen L, Johnson PJ, Macdonald DW (2009) Linkages between household wealth, bushmeat and other animal protein consumption are not invariant: evidence from Rio Muni, Equatorial Guinea. Anim Conserv 12:599-610

Harrison RD, Sreekar R, Brodie JF, Brook S, Luskin M, O’Kelly H, Rao M, Scheffers B, Velho N (2016) Impacts of hunting on tropical forests in Southeast Asia. Conserv Biol 30:972-981

Herdrich DJ (1991) Towards an understanding of Samoan star mounds. J Polyn Soc 100:381-435

Hutchings JA, Reynolds JD (2004) Marine fish population collapses: consequences for recovery and extinction risk. Bioscience 54:297-309

IUCN (2012) Ducula pacifica: BirdLife International: the IUCN red list of threatened species. http://www. iucnredlist.org/details/22691658/0. Accessed 17 Oct 2016

IUCN (2015) Didunculus strigirostris: BirdLife International: the IUCN red list of threatened species. http://www.iucnredlist.org/details/22691890/0. Accessed 17 Oct 2016

Kümpel NF, Milner-Gulland EJ, Cowlishaw G, Rowcliffe JM (2010) Incentives for hunting: the role of bushmeat in the household economy in rural Equatorial Guinea. Hum Ecol 38:251-264

Lyver PO, Jones CJ, Belshaw N, Anderson A, Thompson R, Davis J (2015) Insights to the functional relationships of Māori harvest practices: customary use of a burrowing seabird. J Wildl Manag 79:969-977

Mace GM, Collar NJ, Gaston KJ, Hilton-Taylor C, Akçakaya HR, Leader-Williams N, Milner-Gulland EJ, Stuart SN (2008) Quantification of extinction risk: IUCN's system for classifying threatened species. Conserv Biol 22:1424-1442

McCauley DJ, Pinsky ML, Palumbi SR, Estes JA, Joyce FH, Warner RR (2015) Marine defaunation: animal loss in the global ocean. Science 347:1255641 
McConkey KR, Drake DR (2006) Flying foxes cease to function as seed dispersers long before they become rare. Ecology 87:271-276

Merlin MD, Juvik JO (1985) Bird protection in Western Samoa. Oryx 19:97-103

Mills JA (1994) The Asian trade in bears and bear parts: impacts and conservation recommendations. Int Conf Bear Res Manag 9:161-167

Milner-Gulland EJ, Bennett EL (2003) Wild meat: the bigger picture. Trends Ecol Evol 18:351-357

MNRE (1998) Government of Samoa national report to the convention on biological diversity. Ministry of Natural Resources and Environment, Apia

MNRE (2006) Recovery plan for the Manumea or toothbilled pigeon: 2006-2016. Ministry of Natural Resources and Environment, Apia

Ostrom E (2008) The challenge of common-pool resources. Environ Sci Policy Sustain Dev 50:8-21

Park G, Hay R, Whistler A, Lovegrove T (1992) The national ecological survey of Western Samoa. In: The conservation of biological diversity in the coastal lowlands of Western Samoa. New Zealand Department of Conservation, Wellington, p 196

Peres CA, Emilio T, Schietti J, Desmoulière SJ, Levi T (2016) Dispersal limitation induces long-term biomass collapse in overhunted Amazonian forests. Proc Natl Acad Sci USA 113:892-897

Phelps J, Biggs D, Webb EL (2016) Tools and terms for understanding illegal wildlife trade. Front Ecol Environ 14:479-489

Ponzi D, McCauley DS, Calanog LA (eds) (2004) Volume II: Case studies. Mainstreaming the environment in development planning and management. Pacific region environmental strategy 2005-2009. Asian Development Bank

Powlesland RG, Butler DJ, Westbrooke IM (2008) Was tropical cyclone Heta or hunting by people responsible for decline of the Lupe (Ducula pacifica) (Aves: Columbidae) population on Niue during 19942004? Pac Sci 62:461-471

Pritchard W (1866) Polynesian reminiscences on life in the South Pacific Islands. Chapman and Hall, London

Robinson JG, Bennett EL (2002) Will alleviating poverty solve the bushmeat crisis? Oryx 36:332

SBS (2016) Samoa household and income and expenditure survey 2013/2014. Economics and Statistics Division, Samoa Bureau of Statistics (SBS), Samoa

Schaller GB, Rabinowitz A (2009) The saola or spindlehorn bovid Pseudoryx nghetinhensis in Laos. Oryx 29:107-114

Steinmetz R, Srirattanaporn S, Mor-Tip J, Seuaturien N (2014) Can community outreach alleviate poaching pressure and recover wildlife in South-East Asian protected areas? J Appl Ecol 51:1469-1478

Stirnemann RL, Potter MA, Butler D, Minot EO (2016) Slow life history traits in an endangered tropical island bird, the Ma'oma'o. http://www.core/journals/bird-conservation-international/article/slow-life-history-traits-in-an-endangered-tropical-island-bird-the-maomao/DBC437B8AF4C3E6799C8573B93937F70. Accessed 17 Nov 2016

Szabo JK, Khwaja N, Garnett ST, Butchart SHM (2012) Global patterns and drivers of avian extinctions at the species and subspecies level. PLoS ONE 7:e47080

Tuck GN, Polacheck T, Croxall JP, Weimerskirch H (2001) Modelling the impact of fishery by-catches on albatross populations. J Appl Ecol 38:1182-1196

van Vliet N, Mbazza P (2011) Recognizing the multiple reasons for bushmeat consumption in urban areas: a necessary step toward the sustainable use of wildlife for food in Central Africa. Hum Dimens Wildl $16: 45-54$

Vasco C, Sirén A (2016) Correlates of wildlife hunting in indigenous communities in the Pastaza Province, Ecuadorian Amazonia. Anim Conserv 19:422-429

Walker JS (2007) Geographical patterns of threat among pigeons and doves (Columbidae). Oryx 41:289-299

Ward RG, Ashcroft P (1998) Samoa: mapping the diversity. Institute of Pacific Studies

Watling D (2004) A guide to the birds of Fiji and Western Polynesia: including American Samoa, Niue, Samoa, Tokelau, Tonga, Tuvalu, and Wallis and Futuna. Environmental Consultants, Suva

Whistler AW (1980) The vegetation of eastern Samoa. Allertonia 2:45-158

Zhang L, Hua N, Sun S (2008) Wildlife trade, consumption and conservation awareness in southwest China. Biodivers Conserv 17:1493-1516 